\title{
Analisis Kebutuhan Bahasa Mandarin Dunia Usaha Di Jawa Barat
}

\author{
Rika Limuria', Septerianie Sutandi ${ }^{2}$ \\ Fakultas Sastra Universitas Kristen Maranatha' \\ rika.limuria@let.maranatha.edu \\ Fakultas Sastra Universitas Kristen Maranatha² \\ septerianie.sutandi@let.maranatha.edu
}

\begin{abstract}
China's increasing investment in Indonesia has resulted in higher demand of professional that is fluent in Chinese for business purposes. This research aims to analyze the needs of stakeholder and learners on Chinese for business purposes, and to evaluate whether this needs have been answered by curriculum implementation in higher education level. The writer analyzes the needs of stakeholder and learners by using quantitative qualitative method, evaluates teaching methods and learning materials used in X University in West Java, and compare the analysis of stakeholder and learners' needs to the evaluation of learning materials and teaching method implemented in $X$ University in West Java. This research aims to provide reference of stakeholder and learners' needs on Chinese for business purposes, and thus provide basis for the design of Chinese for business purposes curriculum in Indonesia.
\end{abstract}

Keywords: needs analysis, language learning, Chinese for business purposes, curriculum design, Chinese as a second language

Intisari

Peningkatan investasi Tiongkok di Indonesia berdampak pada peningkatan kebutuhan tenaga ahli yang terampil berbahasa Mandarin di bidang dunia usaha. Penelitian ini bertujuan untuk memahami kebutuhan stakeholder dan pembelajar terhadap keterampilan bahasa Mandarin bidang dunia usaha, dan mengevaluasi apakah kebutuhan ini telah terpenuhi lewat implementasi kurikulum di perguruan tinggi. Penelitian ini menganalisis kebutuhan stakeholder dan pembelajar dengan metode kuantitatif kualitatif, mengevaluasi metode pengajaran dan materi ajar yang dipakai di Universitas X di Jawa Barat, serta membandingkan hasil analisis kebutuhan stakeholder dan pembelajar dengan hasil evaluasi materi dan metode pengajaran di Universitas X di Jawa Barat. Penelitian ini diharapkan dapat menyediakan referensi mengenai kebutuhan stakeholder dan pembelajar akan bahasa Mandarin bidang dunia usaha, dan menjadi acuan bagi pengembangan kurikulum bahasa Mandarin bidang dunia usaha di Indonesia.

Kata kunci: analisis kebutuhan, pembelajaran bahasa, bahasa Mandarin bidang dunia usaha, rancangan kurikulum, bahasa Mandarin sebagai bahasa kedua 


\section{Pendahuluan}

Seiring dengan semakin pesatnya kemajuan Tiongkok dalam aspek industri dan perdagangan, semakin banyak pula negara yang menjalin komunikasi dan kerjasama dengan Tiongkok. Menurut Deputi bidang Pengendalian dan Pengawasan Penanaman Modal Badan Koordinasi Penanaman Modal, Azhar Lubis, nilai investasi Tiongkok meningkat dari US\$ 600 juta (Rp 7,98 triliun) menjadi US\$ 2,7 miliar (Rp 35,9 triliun). Investasi Tiongkok di Indonesia terentang dari pembangunan fasilitas pengolahan mineral (smelter), properti, perkebunan, pembangkit listrik sampai sektor jasa, seperti perhotelan (Tempo.co. 2017).

Peningkatan nilai investasi Tiongkok di Indonesia sejalan dengan harapan terhadap perkembangan hubungan kerjasama antara Indonesia dengan Tiongkok khususnya dalam bidang perekonomian. Perkembangan ini menegaskan bahwa kebutuhan tenaga kerja yang menguasai Bahasa Indonesia dan Bahasa Mandarin semakin meningkat. Program studi bahasa Mandarin Universitas X di Jawa Barat (selanjutnya disingkat UXJB) berusaha menjawab kebutuhan ini dengan menjadikan keterampilan berbahasa
Mandarin di bidang dunia usaha sebagai salah satu konsentrasi dalam kurikulumnya. Tujuan pembelajaran dari mata kuliah Bahasa Mandarin Dunia Usaha tersebut adalah membekali mahasiswa dengan istilah bahasa Mandarin dalam dunia bisnis dan perdagangan internasional, untuk kemudian diterapkan dalam komunikasi lisan dan tulisan bidang dunia usaha. Serangkaian pembelajaran Bahasa Mandarin Dunia Usaha yang tepat dan efektif akan dapat mendukung kondisi bisnis dan perekonomian di masa yang akan datang, serta memenuhi kebutuhan stakeholder dan pembelajar akan sumber daya insani yang memiliki keterampilan bahasa Mandarin di bidang dunia usaha. Berdasarkan pemikiran tersebut, artikel ini akan membahas tentang kebutuhan stakeholder dan pembelajar terhadap keterampilan berbahasa Mandarin, dan mengevaluasi apakah metode pengajaran dan materi ajar yang diterapkan di program studi Bahasa Mandarin UXJB dapat memenuhi kebutuhan stakeholder dan pembelajar akan keterampilan bahasa Mandarin di bidang dunia usaha.

Berdasarkan latar belakang yang telah dikemukakan di atas, maka rumusan masalah dari penelitian ini adalah: 
1. Apa saja kebutuhan para pembelajar di program studi bahasa Mandarin Universitas X di Jawa akan keahlian bahasa Mandarin dunia usaha?

2. Apakah metode pengajaran dan materi ajar mata kuliah Bahasa Mandarin Dunia Usaha yang digunakan di program studi bahasa Mandarin Universitas X di Jawa Barat dapat memenuhi kebutuhan para pembelajar?

3. Bagaimana kebutuhan stakeholder akan keahlian bahasa Mandarin di bidang dunia usaha?

4. Apakah metode pengajaran dan materi ajar mata kuliah bahasa Mandarin Dunia Usaha yang diterapkan di program studi bahasa Mandarin Universitas X di Jawa Barat dapat memenuhi kebutuhan stakeholder akan keahlian bahasa Mandarin di bidang dunia usaha?

\section{Metodologi Penelitian}

Pendekatan kuantitatif kualitatif akan digunakan untuk menjawab rumusan masalah dalam penelitian ini. Metode kuantitatif akan dipakai untuk menganalisis kebutuhan stakeholder dan pembelajar akan keterampilan berbahasa Mandarin di bidang dunia usaha, sedangkan metode kualitatif akan dipakai untuk menganalisis kesesuaian materi ajar dan metode pengajaran yang diterapkan dalam proses pembelajaran bahasa Mandarin dunia usaha di UXJB dengan kebutuhan stakeholder dan pembelajar.

Data kuantitatif diperoleh dari kuesioner yang didistribusikan kepada para pembelajar bahasa Mandarin dunia usaha di UXJB dan para stakeholder yang bergerak di bidang dunia usaha di provinsi Jawa Barat. Evaluasi terhadap materi ajar dan metode pengajaran bahasa Mandarin dunia usaha yang diterapkan di UXJB dilakukan lewat metode wawancara bebas terpimpin (semi-structured interview). Pada tanggal 1 Agustus 2017, dilakukan wawancara terhadap pimpinan instansi mengenai kebijakan dan rancangan kurikulum di instansi terkait. Wawancara juga dilakukan kepada pengajar untuk memahami implementasi kurikulum serta kendala yang dihadapi dalam proses pembelajaran.

Mekanisme analisis kebutuhan akan dilakukan dari 4 sudut pandang, yaitu dari sudut pandang pengguna (stakeholder), dari sudut pandang pembelajar, yang meliputi mahasiswa dan alumni, dari sudut pandang pimpinan instansi dan juga dari sudut pandang pengajar. 


\section{Hasil dan Pembahasan}

Dalam merancang kurikulum
bahasa Mandarin dunia usaha,
pengajar/pembuat kebijakan harus
melakukan analisis terhadap kebutuhan
pasar dan kebutuhan pembelajar terlebih
dahulu, yang juga disebut sebagai Analisis
Kebutuhan (Needs Analysis). Analisis
kebutuhan merupakan
pendalaman terhadap kebutuhan
pembelajar bahasa dalam proses
pembelajaran, dan juga merupakan
proses penyusunan rancangan
pembelajaran berdasarkan urutan
prioritas (Richards et al., 1985).

$$
\text { Basturkmen (2010, h.19) }
$$
menyatakan analisis kebutuhan merupakan proses pengembangan kurikulum. Bahasa dan keterampilan berbahasa yang diperlukan oleh pembelajar di lingkungan kerjanya di kemudian hari akan diidentifikasi dan dijadikan sebagai rujukan materi pembelajaran yang dikaitkan dengan kemampuan berbahasa pembelajar saat proses pembelajaran tersebut berlangsung, persepsi pembelajar akan kebutuhan pembelajaran dan disesuaiakan dengan konteks pengajaran.

Analisis kebutuhan memberikan informasi mengenai motivasi, pengetahuan dan keterampilan yang dibutuhkan pembelajar, tingkat kedalaman pengetahuan dan keterampilan yang perlu dipelajari pembelajar (Chen, 2011, h. 38).

Analisis kebutuhan juga mendapat tentangan dari beberapa ahli, seperti Widdowson (1983) yang berpendapat bahwa rancangan pembelajaran yang didasarkan pada analisis kebutuhan hanya akan menghasilkan pelatihan keterampilan berbahasa (language training), dan bukan pendidikan bahasa (language education). Para pembelajar hanya dilatih untuk menggunakan bentuk-bentuk bahasa yang terbatas, dan tidak dibekali dengan pengetahuan berbahasa yang menyeluruh dan mendasar. Selain itu, persepsi terhadap kebutuhan adalah hal yang subjektif dan variatif, dan perancang kurikulum harus bisa memilah persepsi manakah yang akan dipakai dan diterapkan dalam rancangan kurikulum pembelajaran (Jasso-Aguilar, 1999). Di sinilah letak tantangan kurikulum berbasis analisis kebutuhan, dimana para perancang kurikulum dan pengajar harus dapat memenuhi kebutuhan pembelajar dan kebutuhan pasar, dan di saat bersamaan juga harus memberikan pengetahuan 
berbahasa yang mendasar pada pembelajar.

Di balik tentangan dari beberapa ahli, analisis kebutuhan tetap digunakan sebagai salah satu proses pengembangan kurikulum. Long (2005, h.130) berpendapat bahwa pelibatan unsurunsur terkait dalam bidang tertentu, misalnya stakeholder dan karyawan dari sebuah instansi memberikan gambaran yang lebih menyeluruh dan mendalam mengenai kebutuhan bahasa yang dibutuhan serta mendukung terciptanya kurikulum yang lebih memadai.

Untuk menganalisis dan mendalami kebutuhan pembelajar, Hutchinson dan Waters (1987, h.55) menginisiasi analisis kebutuhan dari dua aspek, yaitu:

1. Kebutuhan dalam konteks spesifik (Target situation needs)

Yaitu analisis terhadap penggunaan bahasa pada situasi dan konteks yang spesifik, yang ditinjau dari tiga aspek berikut ini:

- Kebutuhan (necessities) Kebutuhan objektif pembelajar akan pengetahuan dan keterampilan bahasa yang harus dikuasai supaya dapat menggunakan bahasa secara efektif di waktu yang akan datang.

- Kekurangan (lacks)
Selisih atau perbedaan antara kebutuhan penggunaan bahasa pembelajar di waktu yang akan datang dengan kemampuan yang dimiliki pembelajar saat ini.

- Harapan (wants)

Harapan pembelajar akan materi yang ingin dipelajari.

2. Kebutuhan pembelajaran (learning needs)

Yaitu kondisi yang dibutuhkan pembelajar dan hal-hal yang perlu dilakukan oleh pembelajar dalam proses belajar mengajar. Kebutuhan pembelajaran dapat dikelompokan ke dalam beberapa aspek sebagai berikut:

- Kondisi fisik, berupa tempat belajar, materi belajar, waktu belajar.

- Kondisi psikologis, berupa minat belajar, motivasi.

- Kondisi pengetahuan dan keterampilan, berupa pengetahuan yang dimiliki saat ini, cara belajar.

- Kondisi pendukung, berupa pengajar dan pembuat kebijakan.

Analisis kebutuhan dapat dilakukan dengan metode observasi, wawancara, distribusi kuesioner, dll. Long Jurnal Lingua Applicata Volume 2 Nomor 1 September 2018

Hal. 5 
(2005, h. 150) memberikan contoh dalam melakukan analisis kebutuhan pegawai yang bergerak di bidang industri pariwisata, apabila informasi yang tersedia tidak cukup, maka peneliti perlu melakukan wawancara bebas (unstructured interview) yang mendalam dengan para stakeholder dari berbagai bidang, misal pimpinan dari berbagai jenis hotel, pemilik toko oleh-oleh, restoran, biro perjalanan wisata, perusahaan rental mobil, dan juga turis itu sendiri.

Proses pengumpulan data melalui wawancara dan kuesioner merupakan sebuah proses dimana para narasumber disajikan dengan sejumlah pertanyaan, kemudian mengkaji dan merespon pertanyaan yang diajukan. Data ini kemudian akan dianalisis oleh para peneliti. Keseluruhan proses ini memungkinkan terjadinya distorsi terhadap persepsi, baik oleh narasumber itu sendiri maupun oleh peneliti. Oleh sebab itu, analisis kebutuhan akan lebih terukur apabila ditambah dengan proses observasi. Dengan observasi peneliti dapat mendalami sebuah proses kegiatan yang lebih alami dan lebih menyeluruh (Long, 2005, h.150).

Analisis kebutuhan tidak hanya dipakai untuk menganalisis kebutuhan stakeholder dan pembelajar, tetapi juga bermanfaat bagi pengajar dan pembuat kebijakan, seperti yang diutarakan oleh Chen (2009). Menurut Chen, analisis kebutuhan dapat digunakan sebagai:

- dasar untuk membuat atau merevisi kurikulum pembelajaran bahasa;

- dasar untuk merancang dan menjalankan isi kurikulum pembelajaran bahasa;

- dasar untuk menentukan tujuan dan metode pembelajaran bahasa;

- Rujukan untuk proses evaluasi pembelajaran yang sedang berjalan saat ini (Cheng, 2011, h. 40).

Pembelajaran bahasa kedua dalam bidang dunia usaha adalah sebuah proses pembelajaran aspek komunikatif yang berhubungan dengan bidang dunia usaha dengan menggunakan bahasa kedua. Pada prinsipnya, pada pembelajaran bahasa kedua dalam bidang dunia usaha, pengajar mengajarkan dan melatih keterampilan komunikasi menggunakan bahasa kedua dalam bidang dunia usaha, bukan mengajarkan pengetahuan dunia usaha (Li, 1998, h. 331).

Jika dibandingkan dengan pembelajaran komunikasi dalam kehidupan sehari-hari, komunikasi dalam bidang dunia usaha meliputi topik dan konteks yang lebih spesifik dan terbatas. Kegiatan dalam bidang dunia usahapun Jurnal Lingua Applicata Volume 2 Nomor 1 September 2018

Hal. 6 
umumnya memiliki prosedur kegiatan yang sudah pasti, sehingga isi pembicaraan umumnya sudah memiliki pola tertentu. Karena faktor yang disebutkan di atas, pada proses pembelajaran bahasa kedua dalam bidang dunia usaha, pengajar dapat memberikan topik pembicaraan dan konteks secara spesifik, serta mengajarkan kosakata dan struktur kalimat dengan lebih spesifik.

Komunikasi dalam bidang dunia usaha umumnya menggunakan ragam bahasa formal, serta dilakukan pada konteks dan situasi formal. Selain itu, komunikasi dalam bidang dunia usaha (misal: proses negosiasi) memerlukan seni dan teknik komunikasi yang memadai. Pengajar harus memberikan pengetahuan yang cukup kepada pembelajar supaya komunikasi dalam bidang dunia usaha yang dilakukan oleh pembelajar berjalan lancar, tepat dan logis.

Untuk meningkatkan kualitas pengajaran, pengajar dan pembuat kebijakan perlu melakukan evaluasi materi ajar. Evaluasi materi ajar adalah peninjauan dan penilaian terhadap desain materi ajar dan penggunaan materi ajar yang dilakukan berdasarkan prinsip atau standar tertentu. Evaluasi materi ajar sangat bermanfaat bagi penulisan, pemilihan, atau penggunaan materi ajar (Li, 2011, h.319-320). Evaluasi materi ajar dapat dilakukan sebelum materi ajar digunakan, untuk menentukan akan digunakan atau tidaknya materi ajar tersebut; saat materi ajar sedang digunakan, untuk menentukan perlu tidaknya dilakukan pengaturan kembali atau penambahan terhadap materi ajar tersebut; setelah materi ajar selesai digunakan, untuk menentukan apakah materi ajar tersebut akan terus digunakan di masa mendatang.

Walaupun sampai dengan saat ini belum ada sebuah standar kerangka evaluasi materi ajar bahasa kedua yang diakui secara umum ( $\mathrm{Li}$, 2012, h.273), namun ada beberapa kerangka evaluasi yang cukup banyak digunakan. Salah satunya adalah kerangka evaluasi materi ajar yang dibuat oleh Grant. Grant (1987) merancang kerangka evaluasi yang terbagi menjadi tiga kelompok untuk mengevaluasi hubungan isi dari materi ajar dengan kebutuhan pembelajar, pengajar, dan kurikulum yang digunakan oleh instansi pendidikan pengguna materi ajar tersebut (Li, 2012, h. 274-275).

Metode penelitian yang dipakai dalam penelitian ini adalah metode kuantitatif kualitatif, dimana metode Jurnal Lingua Applicata Volume 2 Nomor 1 September 2018 
kuantitatif lebih menekankan pada pengujian hipotesis dan penggunaan instrumen penelitian yang terukur, berupa kuesioner, sedangkan metode kualitatif lebih menekankan pada observasi dan wawancara bebas sebagai instrumen penelitian (Chen, 2007, h.1314). Mertens (2005) juga menyebutkan bahwa metode kuantitatif kualitatif (atau yang dikenal sebagai metode campuran) dapat digunakan untuk meneliti kondisi yang memiliki kompleksitas sosial yang tinggi. Metode ini digunakan untuk meningkatkan investigasi terhadap objek penelitian, serta menambah variabel yang dapat digunakan untuk menarik kesimpulan penelitian (Dörnyei, 2007, h.149).

\section{Instrumen Penelitian}

Instrumen penelitian yang digunakan dalam menganalisis kebutuhan stakeholder adalah kuesioner, yang terdiri dari sebelas butir pertanyaan mengenai latar belakang dari responden, empat belas butir pertanyaan tertutup dengan menggunakan skala Likert dan satu butir pertanyaan terbuka. Tujuan dari instrumen penelitian ini adalah untuk mendapatkan gambaran mengenai kebutuhan stakeholder akan staf bilingual di perusahaan yang bersangkutan, kriteria dan keterampilan seperti apa yang perlu dikuasai oleh staf bilingual tersebut.

Instrumen penelitian yang digunakan untuk menganalisis kebutuhan pembelajar adalah kuesioner, yang terdiri dari tujuh pertanyaan tertutup dengan menggunakan skala Likert, tiga pertanyaan terbuka dan enam pertanyaan tertutup. Tujuan dari instrumen penelitian ini adalah untuk mendapatkan gambaran akan kebutuhan pembelajar, dan penilaian pembelajar akan rancangan pembelajaran Bahasa Mandarin Dunia Usaha yang telah didapatkan selama perkuliahan.

Analisis terhadap rancangan dan implementasi kurikulum melibatkan pimpinan program studi Bahasa Mandarin UXJB dan pengajar Bahasa Mandarin Dunia Usaha di UXJB. Instrumen yang digunakan adalah kuesioner dan wawancara bebas. Kuesioner dan wawancara yang dilakukan terhadap pimpinan program studi bertujuan untuk mendapatkan gambaran atas alasan penyelenggaraan, dasar rancangan dan pemilihan materi ajar; sedangkan kuesioner dan wawancara yang dilakukan terhadap pengajar bertujuan untuk mendapatkan gambaran atas proses implementasi kurikulum Bahasa Mandarin Dunia Usaha di UXJB. 
Analisis

Terhadap

Kebutuhan

Stakeholder

Analisis terhadap kebutuhan

stakeholder digunakan untuk mengukur kebutuhan dalam konteks spesifik (target situation needs). Stakeholder meliputi pemilik, pimpinan ataupun manajer perusahaan; mereka merupakan pihak yang bekerja dan banyak berinteraksi dengan tenaga bilingual. Pengalaman stakeholder saat berinteraksi dengan tenaga bilingual memberikan gambaran tersendiri mengenai keterampilan yang perlu dimiliki oleh staf bilingual. Kuesioner dirancang dan didistribusikan kepada stakeholder untuk memahami manfaat dan kendala yang diperoleh stakeholder saat berinteraksi dengan tenaga bilingual, dan persepsi stakeholder akan keterampilan yang perlu dimiliki oleh tenaga bilingual. Pengambilan data dilakukan lewat kuesioner, yang terdiri dari empat pertanyaan tertutup, tiga pertanyaan terbuka, dan dua belas butir pertanyaan untuk mengukur tingkat kebutuhan responden akan keterampilan bahasa Mandarin bidang dunia usaha dengan menggunakan skala Likert. Data dalam penelitian ini dianalisis secara kuantitatif dan kualitatif. Kuesioner dibagikan pada stakeholder di Jawa Barat pada bulan Juni 2017. Data dalam penelitian ini diambil dari sembilan orang responden stakeholder, empat orang diantaranya merupakan warga negara Indonesia, sedangkan lima orang diantaranya merupakan warga negara asing. $62 \%$ responden menduduki jabatan manajerial, 25\% menduduki jabatan factory advisor, dan sisanya merupakan staf perusahaan. Jenis perusahaan tempat responden bekerja didominasi oleh perusahaan modal dalam negeri, yaitu sebanyak $62 \%$, sedangkan perusahaan modal asing sebanyak $38 \%$. Bidang usaha yang ditekuni responden didominasi oleh industri tekstil, diikuti industri telekomunikasi dan bidang jasa ekspedisi.

Dari data yang terkumpul, didapatkan bahwa sejumlah $89 \%$ responden mengalami kesulitan berkomunikasi dengan penutur bahasa yang berbeda. $89 \%$ dari total responden mempekerjakan staf bilingual untuk menjembatani komunikasi dengan penutur bahasa yang berbeda. Manfaat yang diberikan oleh tenaga bilingual kepada stakeholder sangat besar, dimana semua responden menyatakan mereka sangat terbantu dengan kehadiran tenaga bilingual. Ketidakpuasan terhadap hasil kerja dan kemampuan tetap terlihat, dimana $62.5 \%$ dari total responden masih Jurnal Lingua Applicata Volume 2 Nomor 1 September 2018 
mengalami kendala dalam berkomunikasi dengan staf bilingual di perusahaan masing-masing. Kendala yang timbul datang dari responden stakeholder sendiri, dimana responden stakeholder memiliki keterbatasan dalam kemampuan berbahasa; dan juga dari keterbatasan kemampuan staf bilingual, dimana para responden menyatakan masih terdapat keterbatasan dalam penguasaan istilah khusus bidang dunia usaha, dan juga adanya perbedaan budaya dalam pemakaian bahasa. Keterbatasan ini kerapkali menimbulkan kesalahpahaman dalam berkomunikasi. Oleh sebab itu, seorang tenaga bilingual tidak hanya sebatas memiliki kemampuan berkomunikasi, tetapi juga harus mampu berkomunikasi secara efektif dengan menguasai istilah khusus dan budaya pada kedua bahasa.

Kebutuhan stakeholder akan keterampilan berbahasa Mandarin dibagi ke dalam dua bagian, yaitu kemampuan berbahasa lisan dan kemampuan berbahasa secara tertulis. Deskripsi kemampuan lisan dibagi dalam beberapa tahapan, mulai dari kemampuan reseptif dalam komunikasi lisan sehari-hari, kemampuan produktif dalam komunikasi lisan sehari-hari, kemampuan reseptif dalam komuniasi lisan bidang dunia usaha, kemampuan produktif dalam komunikasi lisan bidang dunia usaha. Persepsi kebutuhan stakeholder akan keterampilan berbahasa Mandarin secara lisan adalah sebesar 4.20 dari skala 5, diuraikan pada tabel di bawah ini.

Tabel 1. Kebutuhan Stakeholder Akan Keterampilan Berbahasa Mandarin Lisan Staf Bilingual

$\begin{array}{llllll}\text { No Pernyataan } & \text { STP } & \text { TP } & B & P & \text { SP }\end{array}$

\begin{tabular}{l|llllll}
1 & Kemampuan untuk & 0 & 0 & 1 & 3 & 5
\end{tabular} memahami

informasi dalam

bahasa Mandarin

secara lisan

3

Kemampuan untuk $\quad 0 \quad 0010063$

menyampaikan

informasi dalam

bahasa Mandarin

secara lisan

5

Kemampuan untuk $\quad \begin{array}{lllll}0 & 0 & 0 & 6 & 3\end{array}$

memahami

informasi dalam

bahasa Mandarin

bidang dunia usaha

secara lisan

$\begin{array}{llllll}\text { Kemampuan untuk } & 0 & 0 & 0 & 7 & 2\end{array}$

menyampaikan

informasi/bernegosi

asi dalam bahasa

Mandarin bidang

dunia usaha secara

lisan

9

Kemampuan untuk

menggunakan istilah 


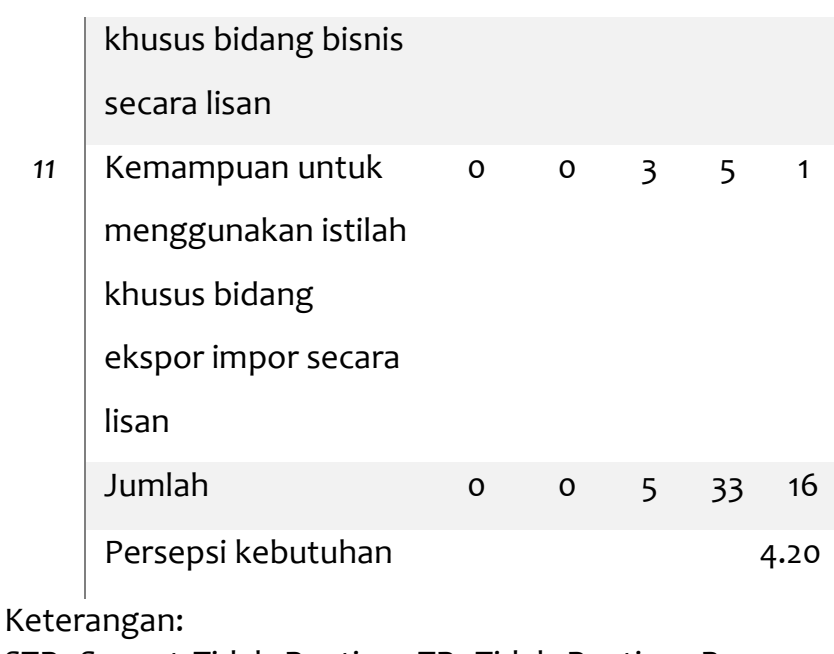

STP: Sangat Tidak Penting; TP: Tidak Penting; B: Biasa; P: Penting; SP: Sangat Penting

Sumber: diolah oleh peneliti, 2017.

Uraian di atas menunjukkan persepsi stakeholder terhadap keterampilan berbahasa Mandarin lisan yang perlu dimiliki oleh tenaga bilingual. Uraian di atas menunjukkan kemampuan berbahasa reseptif dan produktif tenaga bilingual menempati prioritas teratas, baik kemampuan untuk komunikasi sehari-hari maupun kemampuan komunikasi dalam bidang dunia usaha, sedangkan persepsi mengenai kemampuan untuk menggunakan istilah khusus bidang bisnis dan ekspor impor tidak memainkan peranan sebesar kemampuan komunikasi lisan. Hal ini menunjukkan penguasaan dan penggunaan istilah khusus bidang bisnis dianggap penting, tapi tidak menjadi syarat yang mutlak dan mendasar.

Selain mengukur keterampilan komunikasi lisan, penelitian ini juga mengukur kebutuhan stakeholder akan keterampilan komunikasi secara tertulis. Deskripsi kemampuan komunikasi tertulis dibagi dalam beberapa tahapan, yaitu kemampuan reseptif dalam komunikasi tertulis sehari-hari, kemampuan produktif dalam komunikasi tertulis sehari-hari, kemampuan reseptif dalam komunikasi tertulis bidang dunia usaha, kemampuan produktif dalam komunikasi tertulis bidang dunia usaha. Persepsi stakeholder terhadap kebutuhan akan keterampilan berbahasa Mandarin secara tertulis adalah sebesar 3.83 dari skala 5 , seperti yang diuraikan pada tabel di bawah ini.

Tabel 2. Kebutuhan Stakeholder Akan Keterampilan Berbahasa Mandarin Tertulis Staf Bilingual

No Pernyataan STP TP $B \quad$ P $\quad$ SP

\begin{tabular}{|c|c|c|c|c|c|c|}
\hline 2 & $\begin{array}{l}\text { Kemampuan } \\
\text { untuk } \\
\text { memahami } \\
\text { informasi } \\
\text { dalam bahasa } \\
\text { Mandarin } \\
\text { secara tertulis }\end{array}$ & 0 & 1 & 0 & 4 & 4 \\
\hline 4 & $\begin{array}{l}\text { Kemampuan } \\
\text { menyampaikan } \\
\text { informasi } \\
\text { dalam bahasa } \\
\text { Mandarin } \\
\text { secara tertulis }\end{array}$ & 0 & 1 & 2 & 4 & 2 \\
\hline
\end{tabular}




untuk
menggunakan
istilah khusus
bidang ekspor

Sumber: diolah oleh peneliti, 2017

Data di atas menunjukkan keterampilan komunikasi tertulis (3.83) tenaga bilingual tidak sebesar keterampilan komunikasi lisan (4.20). Hal ini menunjukkan kebutuhan stakeholder akan kemampuan komunikasi lisan tenaga bilingual masih lebih tinggi dibanding kemampuan komunikasi tertulis. Data juga menunjukkan kemampuan untuk menggunakan istilah khusus bidang dunia usaha lebih dibutuhkan dibanding kemampuan untuk menggunakan istilah khusus bidang ekspor impor. Ini menunjukkan kemampuan untuk menggunakan istilah khusus bidang ekspor impor belum merupakan kebutuhan yang mendasar, kemampuan untuk berkomunikasi dalam bahasa tertulis dianggap jauh lebih penting dibanding penguasaaan terhadap istilah khusus bidang ekspor impor.

Selain kemampuan untuk menggunakan istilah khusus bidang ekspor impor, kebutuhan akan pengetahuan terhadap kebijakan ekspor impor juga diukur dalam penelitian ini. Persepsi kebutuhan pengetahuan staf bilingual akan kebijakan ekspor impor, menempati urutan terbawah, yaitu 3.66. Data ini menunjukkan kebutuhan akan pengetahuan tenaga bilingual akan kebijakan ekspor impor tidak sebesar persepsi stakeholder terhadap kebutuhan Jurnal Lingua Applicata Volume 2 Nomor 1 September 2018

Hal. 12 
kebutuhan akan keterampilan berbahasa tenaga bilingual. Hal ini sejalan dengan peran tenaga bilingual, yaitu sebagai tenaga profesional yang mampu menjembatani komunikasi antara dua penutur bahasa yang berbeda. Tingkat kepuasan stakeholder terhadap keterampilan tenaga bilingual di Indonesi juga diukur dalam penelitian ini. Dalam skala Likert, tingkat kepuasan stakeholder akan keterampilan SDM bilingual di Indonesia adalah 4.20. Data ini menunjukkan dari segi kualitas, tenaga bilingual yang tersedia di Indonesia saat ini telah memenuhi standar kebutuhan stakeholder. Para responden stakeholder juga diminta untuk mendeskripsikan keterampilan yang perlu dimiliki oleh tenaga bilingual. Deskripsi yang diberikan oleh para responden stakeholder adalah sebagai berikut:

- Tenaga bilingual memiliki 4 keterampilan berbahasa (mendengar, berbicara, membaca, dan menulis) yang memadai.

- Tenaga bilingual mempunyai tingkat fleksibilitas kerja yang cukup tinggi, dapat menerjemahkan secara kontekstual, serta mempunyai pengetahuan dan pemahaman budaya yang cukup.

- Tenaga bilingual mempunyai pengetahuan peribahasa dan kosakata bidang dunia usaha.

- Tenaga bilingual mempunyai kemampuan komunikasi yang baik, setara dengan HSK Level 4 atau 5 .

- Tenaga bilingual merupakan pribadi yang energik, loyal, bertanggung jawab, fleksibel dalam penempatan kerja, berwawasan luas, menguasai istilah teknis dalam bahasa Mandarin secara lisan maupun tertulis.

Dapat disimpulkan bahwa bagi para stakeholder, kemampuan tenaga bilingual untuk berbahasa Mandarin secara lisan lebih penting dibanding kemampuan tertulis, sedangkan pengetahuan akan kebijakan ekspor impor perlu untuk dikuasai, tapi tidaklah merupakan kebutuhan yang mendasar.

\section{Analisis Terhadap Kebutuhan Pembelajar}

Dalam penelitian ini, kebutuhan pembelajar dianalisis dari dua aspek, yaitu kebutuhan pencapaian (target situation needs) dan kebutuhan pembelajaran (learning needs). Kebutuhan pencapaian meliputi kebutuhan objektif yang ingin Jurnal Lingua Applicata Volume 2 Nomor 1 September 2018

Hal. 13 
dicapai pembelajar, kondisi dan kendala yang dihadapi pembelajar dalam proses pembelajaran, dan harapan yang ingin dicapai lewat proses pembelajaran. Kebutuhan pembelajaran meliputi sarana dan prasarana pembelajaran, motivasi belajar, evaluasi terhadap materi dan metode pengajaran. Data mengenai kebutuhan pembelajar dikumpulkan lewat kuesioner, yang terdiri dari empat pertanyaan terbuka, empat pertanyaan tertutup, dan tujuh pernyataan untuk mengevaluasi kebutuhan pembelajaran dengan menggunakan skala Likert.

Kebutuhan pencapaian pembelajar yang dikumpulkan lewat kuesioner ini meliputi motivasi belajar dan harapan objektif pembelajar. Dari analisis diperoleh fakta bahwa motivasi utama dalam mempelajari bahasa Mandarin dunia usaha adalah untuk berwirausaha, kesadaran akan adanya peningkatan kerjasama antara Indonesia dan Tiongkok dalam berbagai bidang usaha, serta peningkatan jumlah perusahaan modal asing di Indonesia, yang berdampak pada kebutuhan akan staf bilingual. Kondisi perkembangan inilah yang memotivasi pembelajar untuk menguasai bahasa Mandarin bidang dunia usaha. Harapan pembelajar adalah untuk menguasai bahasa Mandarin bidang dunia usaha secara lebih mendalam dan menyeluruh, menguasai istilah khusus di bidang dunia usaha, dan memahami perbedaan budaya antara Indonesia dan Tiongkok untuk meminimalisir kesalahpahaman dalam komunikasi. Realisasi objektif dari harapan pembelajar harus berkesinambungan dengan kondisi kemampuan pembelajar saat proses pembelajaran berlangsung. Data menunjukkan saat proses pembelajaran berlangsung, kemampuan responden masih di bawah harapan dari responden pembelajar itu sendiri. Hal ini terlihat dari berbagai kesulitan pembelajaran yang disampaikan oleh responden pembelajar, seperti penguasaan terhadap kosakata bidang dunia usaha, penguasaan terhadap ragam bahasa formal, pemahaman akan komunikasi bidang dunia usaha yang masih sangat minim, dan keterampilan berbahasa yang masih terbatas. Perbedaan signifikan antara kondisi pembelajar (lacks) dan harapan pembelajar (hopes) memberikan tugas tersendiri bagi pengajar dan pembuat kebijakan untuk merancang materi pembelajaran yang mampu menjembatani kondisi pembelajar saat ini untuk mencapai harapan pembelajar lewat proses pembelajaran yang sistematis dan terarah. 
Evaluasi terhadap kebutuhan pembelajaran yang dikumpulkan lewat kuesioner meliputi empat aspek yang diutarakan oleh Hutchinson dan Waters (1987), yaitu kondisi fisik, kondisi psikologis, kondisi pengetahuan dan keterampilan, dan kondisi pendukung. Persepsi pembelajar terhadap aspek kebutuhan pembelajaran dari segi kondisi fisik adalah sebesar 3.92. Sebanyak 10 orang responden menilai fasilitas yang disediakan sudah baik, 3 orang menilai fasilitas yang disediakan cukup memadai, dan 1 orang responden menilai fasilitas yang disediakan kurang meningkatkan semangat siswa dalam belajar. Responden juga berpendapat bahwa tempat dan fasilitas belajar seharusnya tidak dibatasi hanya dalam ruang kelas saja, tetapi dilengkapi dengan latar yang lebih variatif untuk memotivasi pembelajar dalam proses pembelajaran. Untuk alokasi waktu belajar, 12 orang responden menilai sudah sangat efektif, sedangkan 2 responden berpendapat alokasi waktu belajar cukup memadai. Dari segi media ajar, 9 orang berpendapat media ajar yang digunakan oleh dosen sudah tepat dan beragam, sedangkan 5 orang berpendapat keberagaman media ajar yang digunakan dosen masih dapat ditingkatkan, lewat pemakaian media film, media audiovisual, dan power point. Data ini menunjukkan kebutuhan pembelajar akan fasilitas dan media ajar sudah terpenuhi, hanya saja masih diperlukan peningkatan pada berbagai aspek fisik.

Tabel 3. Persepsi Pembelajar Terhadap Aspek Fisik Kebutuhan Pembelajaran

No Pernyataan STS TS B S SS

\begin{tabular}{|c|c|c|c|c|c|c|}
\hline 1 & $\begin{array}{l}\text { Tempat dan } \\
\text { fasilitas } \\
\text { belajar baik } \\
\text { dan } \\
\text { mendukung } \\
\text { Anda } \\
\text { mempelajari } \\
\text { Bahasa } \\
\text { Mandarin } \\
\text { bidang dunia } \\
\text { usaha. }\end{array}$ & 0 & 1 & 3 & 6 & 4 \\
\hline 2 & $\begin{array}{l}\text { Alokasi waktu } \\
\text { belajar di } \\
\text { kelas cukup } \\
\text { untuk Anda } \\
\text { berlatih } \\
\text { komunikasi } \\
\text { bidang dunia } \\
\text { usaha secara } \\
\text { efektif. }\end{array}$ & 0 & 0 & 2 & 9 & 3 \\
\hline 3 & $\begin{array}{l}\text { Media ajar } \\
\text { yang } \\
\text { digunakan } \\
\text { oleh dosen } \\
\text { tepat dan } \\
\text { beragam. }\end{array}$ & 0 & 0 & 5 & 7 & 2 \\
\hline
\end{tabular}




\begin{tabular}{|lrrrrr} 
Total & 0 & 1 & 10 & 22 & 9 \\
Persepsi & & & & & 3.92 \\
pembelajar & & & & & \\
terhadap & & & & & \\
aspek fisik & & & & &
\end{tabular}

Keterangan:

STS: Sangat Tidak Setuju; TS: Tidak Setuju; B: Biasa; S: Setuju; SS: Sangat Setuju

Sumber: diolah oleh peneliti, 2017

Persepsi pembelajar terhadap kesesuaian isi, ruang lingkup materi, latihan keterampilan berbahasa dan pengetahuan umum yang diberikan dalam mata kuliah Bahasa Mandarin Dunia Usaha dengan kebutuhan pembelajar adalah sebesar 4.21. Data ini menunjukkan materi yang diberikan pada mata kuliah Bahasa Mandari Dunia Usaha di UXJB telah sesuai dengan kebutuhan pembelajar. Sebelas orang responden berpendapat bahwa isi materi ajar Bahasa Mandarin Dunia Usaha sesuai dengan kebutuhan dan minat belajar responden, sedangkan tiga orang berpendapat isi materi ajar cukup memadai, tetapi akan lebih baik apabila proses pembelajaran diikuti dengan studi kasus. Tiga belas orang responden berpendapat ruang lingkup materi, kosakata dan struktur kalimat yang diajarkan cukup luas, latihan keterampilan komunikasi yang diberikan juga sangat membantu responden untuk berkomunikasi secara efektif dalam bidang dunia usaha. Salah seorang responden juga berpendapat untuk mempersiapkan pembelajar dengan kebutuhan dunia usaha, tingkat kedalaman bahasa dan komunikasi pada mata kuliah tersebut dapat ditingkatkan.

Tabel 4. Persepsi Pembelajar Terhadap Aspek Pengetahuan dan Keterampilan Kebutuhan Pembelajaran

No. Pernyataan STS TS B S SS

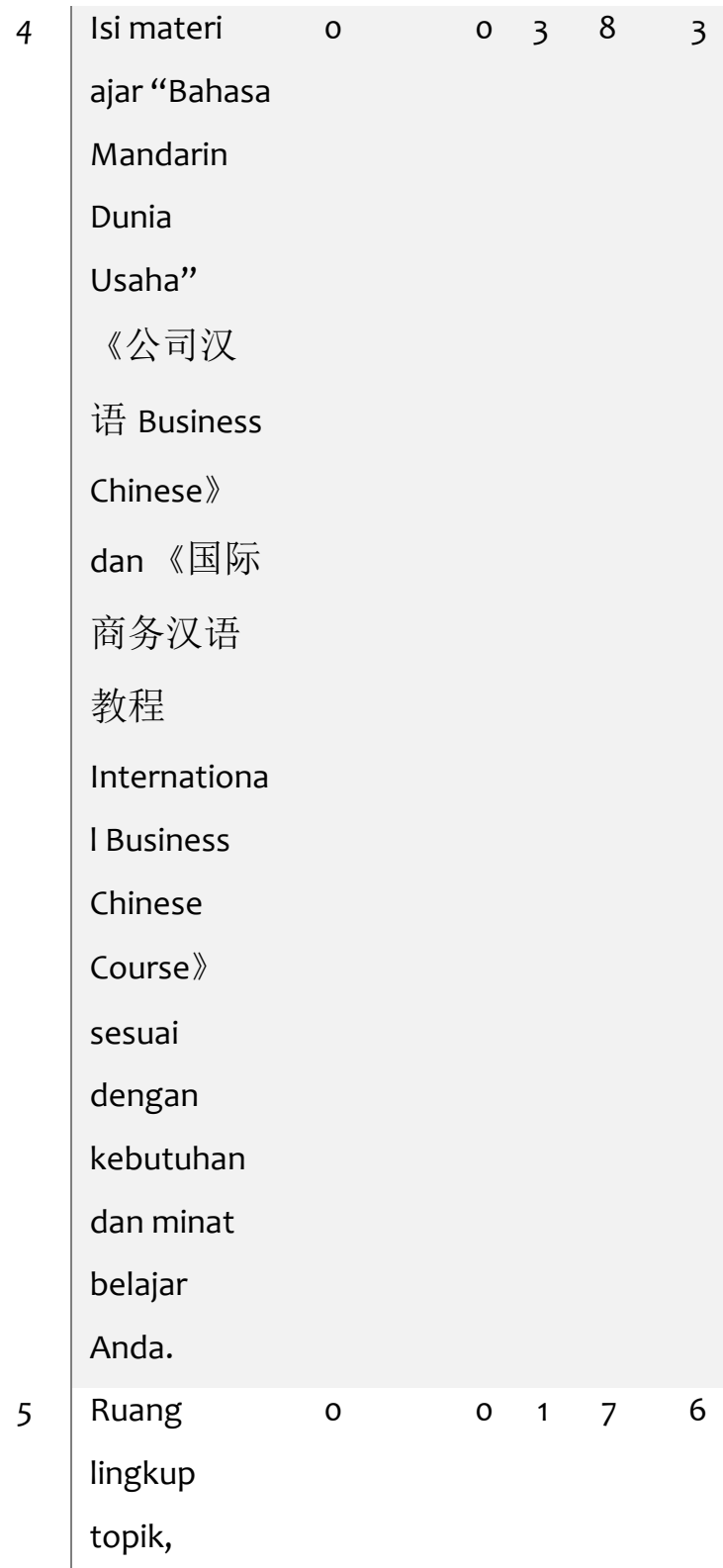




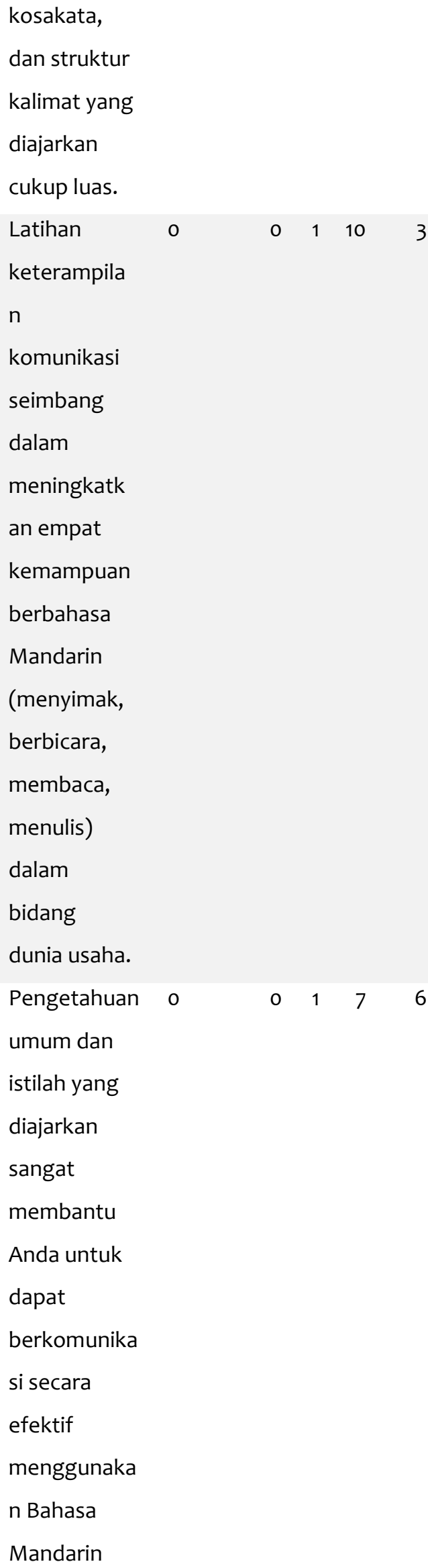

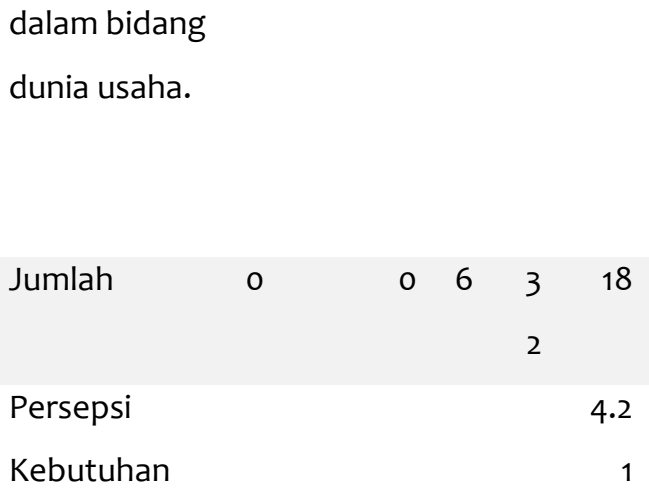

Sumber: diolah oleh peneliti, 2017

Data di atas menunjukkan tingkat kepuasan pembelajar terhadap aspek pengetahuan dan keterampilan sangat tinggi. Hal ini menunjukkan metode ajar dan materi pembelajaran yang diterapkan pada mata kuliah Bahasa Mandarin Dunia Usaha di UXJB telah memenuhi kebutuhan pembelajaran pembelajar. Hal ini juga sejalan dengan ekspektasi pembelajaran yang ingin dicapai oleh pembelajar.

Selain menganalisis kebutuhan pembelajar, penelitian ini juga mengamati kendala yang dihadapi oleh pembelajar dalam proses pembelajaran Bahasa Mandarin Dunia Usaha. Kendala yang disampaikan oleh responden meliputi tingkat familiaritas pembelajar dengan kosakata dan istilah khusus bidang dunia usaha, dan penguasaan responden terhadap ragam bahasa formal, yang meliputi kosakata dan struktur kalimat ragam bahasa formal masih kurang. Para responden juga menyatakan bahwa mata 
kuliah ini memberikan banyak bekal ilmu dalam memasuki dunia kerja, dan berharap mata kuliah ini dapat terus diadakan di program studi Mandarin di UXJB. Frekuensi pengadaan mata kuliah dan tingkat kedalaman materi juga dapat ditingkatkan, karena keterampilan dan pengetahuan yang didapatkan dari mata kuliah ini sangat bermanfaat saat responden memasuki dunia kerja.

\section{Analisis Terhadap Rancangan dan} Implementasi Kurikulum

Untuk memahami alasan penyelenggaraan, dasar rancangan dan implementasi kurikulum, dirangkum informasi dan data dari pembuat kebijakan, yang diwakili oleh pimpinan program studi dan pengajar, selaku pihak yang menjalankan kegiatan pembelajaran. Pengumpulan data dilakukan lewat wawancara bebas terpimpin, dan bertujuan untuk memahami maksud penyelenggaraan mata kuliah Bahasa Mandarin Dunia Usaha, tujuan pembelajaran yang ingin dicapai, dan rancangan kurikulum yang dibuat demi tercapainya tujuan pembelajaran.

Berdasarkan hasil wawancara, penulis mendapatkan bahwa program studi Bahasa Mandarin di UXJB berusaha menjawab tantangan dan perubahan zaman dengan menyediakan mata kuliah Bahasa Mandarin Dunia Usaha. Hal ini sejalan dengan hubungan antara Indonesia dan Tiongkok yang semakin hari semakin erat, terutama dalam bidang bisnis dan ekonomi. Salah satu hal yang mendasari rancangan mata kuliah ini adalah banyaknya perusahaan, baik dari dalam maupun luar pulau Jawa yang mengajukan permintaan lulusan dari program studi ini. Pimpinan instansi berharap lewat penyelenggaraan mata kuliah ini, mahasiswa dapat diperlengkapi dari empat segi keterampilan berbahasa dan juga pengetahuan umum mengenai kebijakan perdagangan di Tiongkok dan di Indonesia, seperti yang diungkapkan pimpinan program studi dalam wawancara

Kebutuhan bahasa Mandarin saat ini di Indonesia makin berhubungan dengan banyak bidang, karena saat ini hubungan bisnis antara pemerintah Indonesia dengan China semakin kuat, kebutuhan akan BMDU semakin tinggi. Harapan kami lulusan bisa memenuhi kebutuhan instansi yang membutuhkan keterampilan Bahasa Mandarin, tidak hanya lisan namun juga tulisan. Siswa juga harus menguasai istilah khusus dalam komunikasi bisnis.

Program studi memfasilitasi hal ini dengan menyediakan mata kuliah Bahasa Mandarin Dunia Usaha, yang merupakan 
mata kuliah wajib yang dilaksanakan dalam dua semester. Rancangan pembelajaran dari mata kuliah ini adalah untuk memperlengkapi siswa dengan keterampilan bahasa Mandarin bidang dunia usaha baik secara lisan maupun tulisan, dan mengasah pengetahuan siswa akan kebijakan perdagangan di Indonesia dan Tiongkok. Dalam mata kuliah Bahasa Mandarin Dunia Usaha, mahasiswa diperlengkapi dengan pengetahuan dan keterampilan berbahasa dalam dunia perkantoran, mulai dari menjadwalkan pertemuan, mengikuti dan memimpin rapat, menghadapi wawancara kerja, melakukan negosiasi bisnis sampai dengan keterampilan berbahasa dalam bidang ekspor impor, seperti melakukan pembelian dari eksportir, mengurus pengiriman barang, mengurus bea cukai, dan menyelesaikan sengketa perdagangan. Tujuan dari rancangan pembelajaran ini adalah untuk melatih keterampilan berbahasa Mandarin siswa, terutama keterampilan berbahasa di bidang dunia usaha.

Untuk mendukung rancangan pembelajaran tersebut, responden menggunakan materi ajar berbahasa Mandarin. Bagi responden, penggunaan materi ajar terbitan luar negeri tentu memiliki kelebihan dan kekurangan tersendiri. Materi ajar tersebut disusun sesuai dengan kondisi dimana materi tersebut dirancang. Oleh sebab itu, untuk menyesuaikan isi materi dengan kondisi dan kebutuhan di Indonesia, pengajar perlu menambahkan informasi mengenai kebijakan perdagangan di Indonesia untuk memperkaya wawasan pembelajar tentang kebijakan di kedua negara. Rancangan kurikulum dan pemilihan materi ajar ditentukan oleh program studi, sedangkan untuk implementasi kurikulum dan pelaksanaan proses belajar mengajar dilaksanakan sepenuhnya oleh pengajar, seperti yang disampaikan oleh pimpinan program studi dalam wawancara

Dasar rancangan kurikulum, dari hasil survei mengenai materi ajar yang perlu diajarkan. Materi ajar terbatas karena hanya memakai terbitan Tiongkok, kondisi bukan kondisi di Indonesia, jadi butuh kerja ekstra dari pengajar untuk menghubungkan dengan kondisi di Indonesia.

Sumber : Data wawancara 2017

Untuk memahami implementasi dan pelaksanaan proses belajar mengajar mata kuliah Bahasa Mandarin Dunia Usaha, dilakukan wawancara bebas terpimpin dengan pengampu mata kuliah 
tersebut. Selain itu juga didistribusikan kuesioner yang terdiri dari sepuluh pertanyaan tertutup untuk mengevaluasi kesesuaian materi ajar dengan kebutuhan pengajar. Melihat hubungan antara Indonesia dan Tiongkok saat ini yang semakin intens, responden berpendapat pembelajar perlu memiliki keterampilan berbahasa Mandarin dalam bidang dunia usaha. Probabilitas pembelajar untuk menggunakan bahasa Mandarin dalam pekerjaan di kemudian hari cukup tinggi, misalnya ketika bekerja di perusahaan Tiongkok di Indonesia, melakukan kerjasama dengan perusahaanperusahaan asing, menghadiri rapat dan lain sebagainya. Maka dari itu, pembelajaran yang dilakukan oleh pengajar pada mata kuliah tersebut bertujuan untuk mengembangkan empat keterampilan berbahasa Mandarin di dalam bidang perkantoran dan bisnis, juga memperlengkapi pembelajar dengan istilah/kosakata khusus bidang dunia usaha yang umum digunakan dalam perkantoran dan perdagangan bisnis internasional.

Dalam pelaksanaan perkuliahan Bahasa Mandarin Dunia Usaha pada program studi bahasa Mandarin UXJB, pengajar mencoba menerapkan beberapa metode ajar. Untuk mengajarkan keterampilan berbahasa Mandarin di bidang dunia usaha, pengajar menggunakan metode role play, studi kasus, dan collaborative learning, seperti yang disampaikan dalam wawancara,

Metode ajar kalau bagi saya ada beberapa, kalau dari bagian paling dasar, saya banyak menggunakan role play, kemudian saya suka menggunakan sistem diskusi kelompok yang akan saya pantau.

Responden pengajar mewajibkan pembelajar untuk menggunakan bahasa Mandarin di ruang kelas, untuk melatih kemampuan berkomunikasi pembelajar, khususnya dalam bidang dunia usaha, seperti disampaikan dalam wawancara,

Diskusi wajib menggunakan bahasa mandarin. Memang ada tantangan tersendiri karena ada beberapa mahasiswa yang kemampuan berbahasa Mandarinnya tidak bagus, sehingga dia lebih memilih untuk diam. Untuk diskusi, yang pertama saya mewajibkan berbahasa mandarin, yang kedua saya sering mengatakan kepada mereka bahwa tidak masalah jika strukturnya masih salah, yang penting kalian sudah mau berbicara tidak hanya diam. Jika mahasiswa hanya diam dan tidak aktif, setiap akhir pertemuan saya akan menunjukan nilai yang mereka peroleh hari ini. Jadi bagi mahasiswa yang selama ini mungkin memang sedikit pemalu dan takut untuk berbicara, dengan melihat hasil yang mereka peroleh cukup rendah karena kurang aktif, mungkin 
mereka akan termotivasi untuk berusaha lebih maksimal lagi dalam hal berbicara serta ikut aktif di dalam kelas.

Sumber : Data wawancara 2017

Selain itu, pemakaian kosakata khusus dalam bidang dunia usaha juga diimplementasikan dalam berbagai tugas dan kegiatan pembelajaran. Responden pengajar juga menyatakan materi ajar yang dipakai sudah memadai, dan merekomendasikan penggunaaan materi ajar tersebut untuk pembelajaran bahasa Mandarin dunia usaha. Kepuasan pengajar terhadap isi materi ajar sebesar 4, sedangkan kesesuaian materi ajar dengan kebutuhan pengajar adalah sebesar 3.67. Namun, persepsi pengajar akan kelengkapan tambahan dari materi ajar yang dapat membantu meningkatkan penguasaan pembelajar terhadap materi masih terbilang rendah, hanya sebesar 2.33. Pengajar juga menilai perlu adanya pemutakhiran terhadap materi ajar, terutama untuk penggunaan beberapa istilah yang berhubungan dengan perkembangan teknologi saat ini, seperti kata "disket" yang sudah tidak relevan dengan perkembangan teknologi terkini.

Hal yang kurang mendukung dalam implementasi kurikulum mata kuliah
Bahasa Mandarin Dunia Usaha pada program studi bahasa Mandarin UXJB adalah sarana dan prasarana. Pengajar merasa fasilitas ruang kelas kurang memadai, sehingga berdampak pada keleluasaan pengajar dalam merancang aktivitas pembelajaran. Pengajar berharap pihak instansi dapat menyediakan fasilitas yang lebih memadai, seperti ruang pertemuan bisnis untuk mendukung proses pembelajaran. Hal ini diharapkan mampu meningkatkan peran serta pembelajar pada aktivitas di kelas. Selain itu, diharapkan ruang-ruang tersebut dilengkapi dengan prasarana seperti laptop dan LCD dengan penempatan yang sesuai, juga didukung alat peraga yang dapat membantu pembelajar mengenali berbagai jenis perlengkapan yang digunakan dalam komunikasi bidang dunia usaha.

Dalam proses pembelajaran Bahasa Mandarin Dunia Usaha, responden pengajar menyatakan bahwa pembelajar mengalami kesulitan untuk menguasai kosakata khusus bidang bisnis dan memahami proses perdagangan internasional. Namun, sebagian besar pembelajar tetap dapat mengikuti setiap kegiatan pembelajaran dengan baik. Walaupun dalam kondisi minimnya lingkungan bahasa Mandarin di Jurnal Lingua Applicata Volume 2 Nomor 1 September 2018

Hal. 21 
Indonesia, pembelajar tetap dapat menyelesaikan berbagai tugas yang diberikan oleh pengajar dengan baik. Pengajar menilai motivasi belajar dan kesadaran pembelajar akan kebutuhan komunikasi bahasa Mandarin dalam bidang dunia usaha masih perlu ditingkatkan. Dalam proses pembelajaran, pembelajar terkadang menganggap materi yang diberikan terlalu sulit. Namun, setelah lulus, banyak pembelajar yang memberikan apresiasi terhadap mata kuliah Bahasa Mandarin Dunia Usaha tersebut.

Dalam proses pembelajaran, pengajar tidak hanya mengajarkan istilah khusus bidang dunia usaha, tetapi juga memperkenalkan budaya bisnis di Tiongkok dan Indonesia. Pengajar menilai kurikulum yang dirancang oleh program studi telah mampu memenuhi kebutuhan stakeholder akan keterampilan bahasa Mandarin, karena pembelajar sudah dibekali dengan keterampilan dan pengetahuan untuk berkomunikasi dalam bidang dunia usaha, baik dalam lingkup internal di sebuah perusahaan maupun melakukan komunikasi bisnis ekspor impor.

\section{Kesimpulan}

Kebutuhan stakeholder akan staf bilingual yang dapat membantu menjembatani komunikasi dengan penutur bahasa yang berbeda sangat tinggi. Stakeholder membutuhkan tenaga bilingual yang memiliki empat keterampilan berbahasa yang memadai, dan mampu menerjemahkan secara kontekstual. Tenaga bilingual juga diharapkan mempunyai pembendaharaan kosakata bidang dunia usaha, pemahaman terhadap peribahasa dan budaya Tionghoa, serta pengetahuan akan kebijakan ekspor impor. Di antara empat keterampilan berbahasa yang dibutuhkan, stakeholder menilai kebutuhan akan keterampilan berbahasa Mandarin secara lisan yang meliputi kemampuan memahami dan menyampaikan informasi merupakan kebutuhan yang paling mendasar. Keterampilan untuk berbahasa Mandarin secara tertulis, baik yang bersifat umum maupun spesifik dalam bidang dunia usaha juga diperlukan oleh stakeholder, namun kebutuhan akan keterampilan tersebut tidak sebesar kebutuhan akan keterampilan komunikasi lisan. Stakeholder berpendapat tenaga bilingual perlu memiliki pemahaman akan 
kebijakan ekspor impor, namun hal ini belum menjadi kebutuhan yang mendasar.

Kebutuhan para pembelajar di program studi bahasa Mandarin UXJB pada keterampilan bahasa Mandarin bidang dunia usaha cukup tinggi. Harapan responden pembelajar lewat pembelajaran bahasa Mandarin dunia usaha adalah mampu menggunakan keterampilan berbahasa untuk berwirausaha ataupun bekerja di bidang dunia usaha. Kebutuhan pembelajaran para pembelajar adalah menguasai keterampilan komunikasi lisan dan tertulis yang dapat membantu pembelajar untuk dapat berkomunikasi secara aktif dalam bidang dunia usaha. Materi ajar, kosakata, dan pengetahuan yang diberikan harus memadai untuk mendukung kebutuhan komunikasi pada bidang dunia usaha sesungguhnya. Latihan penggunaan kosakata dan struktur kalimat, penguasaan terhadap ragam bahasa formal, dan pengetahuan umum dalam bidang dunia usaha akan sangat bermanfaat saat pembelajar memasuki dunia kerja. Untuk memahami bidang dunia usaha secara konkret, pembelajar juga membutuhkan sarana dan prasarana yang memadai. Sarana yang dibutuhkan antara lain ruang kelas, ruang pertemuan bisnis, ruang rapat, dll. Prasarana yang dibutuhkan antara lain alat peraga, media audiovisual, LCD, laptop, dll. Dengan bantuan sarana dan prasarana yang memadai, pembelajar dapat melakukan simulasi berdasarkan kondisi di lapangan.

Berdasarkan analisis yang telah dilakukan dalam penelitian ini, daarancangan kurikulum mata kuliah Bahasa Mandarin Dunia Usaha program studi bahasa Mandarin UXJB sudah memenuhi kebutuhan stakeholder dan pembelajar akan keterampilan bahasa Mandarin di bidang dunia usaha. Penentuan keterampilan komunikasi lisan sebagai fokus utama dari pembelajaran mata kuliah Bahasa Mandarin Dunia Usaha ini juga menunjukkan kesesuaian dengan kebutuhan utama stakeholder saat ini. Selain itu, stakeholder tidak hanya membutuhkan staf bilingual yang mampu berbahasa Mandarin, tetapi juga menguasai kosakata spesifik dan pengetahuan umum bidang dunia usaha serta etika bisnis di kedua negara. Selama proses perkuliahan, pembelajar sudah dipersiapkan dengan keterampilan berbahasa Mandarin dan pengetahuan yang cukup untuk dapat menjalankan perannya dalam kegiatan perkantoran 
ataupun melakukan kegiatan ekspor impor.

Berdasarkan masukan dan evaluasi yang diberikan oleh stakeholder dan pembelajar, terdapat beberapa hal yang dapat ditingkatkan oleh program studi bahasa Mandarin UXJB dan pengajar. Program studi perlu terus melakukan pembaharuan akan materi ajar supaya sesuai dengan perkembangan kebijakan dan teknologi di Indonesia dan di Tiongkok. Selain itu, program studi bahasa Mandarin UXJB juga perlu memfasilitasi mata kuliah Bahasa Mandarin Dunia Usaha dengan ruang kelas dan prasarana yang memadai, sehingga mendorong terlaksananya simulasi yang lebih konkret. Evaluasi terhadap materi ajar juga perlu terus dilakukan untuk mempersiapkan lulusan yang mampu menjawab tantangan zaman.

\section{Daftar Pustaka}

Basturkmen, H. (2006). Ideas and Options in English for Specific Purposes. New Jersey, The United States of America: Lawrence Erlbaum Associates, Inc., Publishers.

Basturkmen, H. (2010). Developing Courses in English for Specific Purposes. Hampshire, The United Kingdom: Palgrave Macmillan.

Chen Q \& L Rude. (2007). Dangdai Jiaoyu Xinlixue. Beijing, China: Beijing Normal University Press.

Cheng, Xiaotang \& Sun Xiaohui. (2011). Yingyu Jiaocai Fenxi Yu Sheji (Xiuding Ban). Beijing, China: Waiyu Jiaoxue Yu Yanjiu Chubanshe.

DÖrnyei, Z. (2007). Research Methods in Applied Linguistics. Oxford, United Kingdom: Oxford University Press.

Hutchinson, T. \& Waters, A. (1987). English for Specific Purposes: A Learning-centred Approach. New York, The United States of America: Cambridge University Press.

Li, Q. (2012). Duiwai Hanyu Jiaocai Tonglun. Beijing, China: Shangwu Yinshuguan.

Li, Q. (2011). Duiwai Hanyu Jiaocai Yanjiu. Beijing, China: Shangwu Yinshuguan.

Li, Y. (1998). Duiwai Hanyu Jiaocheng Kecheng Yanjiu. Beijing, China: Beijing Yuyan Wenhua Daxue Chubanshe.

Long, M H., (2005). Second Language Needs Analysis. New York, The United States of America: Cambridge University Press.

Paltridge, B., \& Starfield, S. (Eds). (2013). The Handbook of English for Specific Purposes. West Sussex, The United Kingdom: John Wiley \& Sons Ltd.

Tempo.co. (2017, Januari 26). BKPM: Investasi Cina Naik Drastis Di 2016. Diakses dari https://bisnis.tempo.co/read/839875/bkp m-investasi-cina-naik-drastis-di-2016 